\title{
COMPETITIVENESS OF FOOD MANUFACTURING OF REPUBLIC OF SERBIA
}

\author{
Dušanka Jovović ${ }^{1}$, David Jovovićc ${ }^{2}$
}

\begin{abstract}
Summary
The subject of paper is export competitiveness of food manufacturing of Republic of Serbia during the period 1996-2016. The analysis of export competitiveness was realised by using the following indicators: Revealed comparative advantage (RCA), Competitiveness growth index (RCA1), Index of net business performance (RCA2), Index of contribution to the trade balance (CTB), Grubel-Lloyd index (GLI) and Michaely index (MI). The results show that $R C A$ values were positive in all years, which speaks of comparative advantage of this industry on the domestic market. Since the RCA1 values were higher than one, they revealed export competitiveness. The positive values of RCA2 during the period 2005-2016 bear witness of contribution of food manufacturing in foreign trade balance of Serbian economy. The average value of CTB index was 3.998 and its positive annual values showed that the contribution of food manufacturing in the total trade balance was positive. The change of GLI values pointed to the loss of ability of the sector to create surplus of national trade balance. Positive annual values of MI confirmed the competitiveness of food manufacturing, but also its insufficient specialisation.
\end{abstract}

Key words: Export competitiveness, indicators of competitiveness of an industry, food manufacturing, Republic of Serbia

JEL: $L 66$

\section{Introduction}

Although characterised by long history of development, food manufacturing is in the constant process of structural adjustment, conditioned by globalisation, liberalisation of world trade and national markets of food products, rapid development of individual markets of developing countries (e.g. India and China), fast development of technology (information-communication technology, biotechnology, genetic engineering etc.) in the domain of (primary and final) agricultural production, distribution and sale, as well as the changes of customers' preferences due to income growth, change of

1 PhD, Full Professor, Faculty of Law, Lole Ribara 29, 38220 Kosovska Mitrovica, 0643749133, dusanka.jovovic@pr.ac.rs

$2 \mathrm{PhD}$, Associate Professor, Faculty of Agriculture, Kopaonička bb, 38228 Lešak, 063203181, jovovicdavid1@gmail.com

EP 2018 (65) 1 (49-64) 
structure (ageing) of the population and life and nourishing habits. All these factors influence development and competitiveness of food manufacturing in the world. The scope of traditional agricultural products is permanently increasing, together with the development of new products and methods of production and organisation of supply chains within food manufacturing.

Favourable geographic position (favourable climate) and relatively large areas of high-class agricultural soil, long tradition of production and relative preservation of productive agricultural and industrial capacities create favourable conditions for further development of food manufacturing in Serbia and larger export on global market.

Food manufacturing is a domain in which Serbia has significant export potential. However, as comparative advantage is not enough per se, export potential of domestic food manufacturing is not adequately exploited due to low competitiveness of domestic food companies and the products themselves.

The subject of research in this paper is export competitiveness of food manufacturing of Serbia during the period 1996-2016. Food manufacturing products are mostly the subject of international trade, which is the reason why their technological characteristics, quality and prices are permanently tested in open economy on both domestic and foreign markets.

Due to the lack of generally accepted synthetic indicator of the achieved level of competitiveness of an industry, the aim is to reach the appropriate answer to the issue of achieved level of competitiveness of food manufacturing of Serbia during the observed period, by using the most frequently applied partial indicators.

In the paper, the competitiveness of food manufacturing of Republic of Serbia was considered with the help of most significant partial indicators of export competitiveness at the level of industry. The calculation of individual indicators respects the fact that many products of food manufacturing differ by their raw origins, degree of procession, i.e. technological complexity and value added such as food and live animals, beverages and tobacco, oil seeds and oleaginous fruits and animal and vegetable oils, fats and waxes. In accordance with Standard International Trade Classification (SITC) Revision 3, food manufacturing includes the following sections:

- 0 - Food and live animals (00 - Live animals, 01 - Meat and meat preparations, 02 - Dairy products and birds'eggs, 03 - Fish, crustaceans, molluscs and preparations thereof, 04 - Cereals and cereal preparations, 05 - Vegetables and fruits, 06 - Sugar, sugar preparations and honey, 07 - Coffee, tea, cocoa, spices, and manufactures thereof, 08 - Feedstuff for animals (excluding unmilled cereals), 09 - Miscellaneous edible products and preparations);

- 1 - Beverages and tobacco (11 - Beverages, 12 - Tobacco and tobacco manufactures);

- 22 - Oil seeds and oleaginous fruits;

- 4 - Animal and vegetable oils, fats and waxes (41 - Animal oils and fats, 42 - Fixed vegetable oils and fats, crude, refined or fractionated, 43 - Processed Animal and vegetable oils and fats). 
The input data for assessment of export competitiveness of food manufacturing of Serbia for the period 1996-2016 are taken over from UNCTADstat database (http:// unctadstat.unctad.org/wds/ReportFolders/reportFolders.aspx?sCS_ChosenLang=en). The selected database makes possible the research related to export and sector competitiveness of food manufacturing of Serbia on domestic and global markets according to SITC Revision 3 International Trade Classification of Products.

Calculation of statistical variables for measuring export competitiveness of food manufacturing was done by using the application in MS Excel, created for this case. By applying appropriate statistical methods the competitiveness of food manufacturing of Serbia was analysed. The interdependence of the selected data was analysed by statistical methods of correlation analysis. The strength and direction of mutual dependence between the selected variables was analysed by calculating the coefficient of correlation.

The obtained data, ordered in statistical series were analysed in order to reveal the structure and mutual influences of structural factors. The aim of statistical analysis was directed towards the detection of "frequency distribution", i.e. detection of distribution of frequency of occurrence of specific properties of numerical expressions. In addition to statistical, correlation analysis was also used, which revealed the existence and important characteristics of relations between data, i.e. different data groups. Correlation analysis cannot describe all properties of the detected relations, but only their existence and frequency.

The paper includes six sections. After the Introduction, the second section analyses the position food manufacturing of Serbia on global market. After the review of the concept of competitiveness at the level of an industry, the third section presents most often used indicators of export competitiveness in certain manufacturing industries. The fourth presents the indicators of competitiveness in Serbia during the period 19962016. In the fifth section the obtained results are discussed. Finally, certain conclusions are sublimated in the sixth section.

\section{Position of food manufacturing of Republic of Serbia on global market}

In the conditions of open market and global competitiveness, competitive position of domestic food manufacturing can be considered by using indicators of export competitiveness, i.e. based on export potential, participation of the sector in total export-trade exchange and follow-up of other export performances of the food manufacturing sector.

During the period 1996-2016 Serbian food manufacturing made the greatest export in 2016, while significant scope of export was recorded in 2014 as well. After gradual decrease of value of export during the period 1996-2000, Serbian food manufacturing permanently recorded increase, which was interrupted in 2009 due to negative effects of global economic crisis. However, in 2010, the value of export increased again until 2015, when it slowed for a while, to reach its highest value in 2016. 
The import mostly followed the dynamics of export until 2008. In 2010, after a significant fall in comparison to 2009, the import firstly stagnated and gradually recovered in the next four years. Gradual increase of import lasted until 2015 and 2016, when it repeatedly decreased.

Serbian food manufacturing realised the largest scope of foreign trade exchange in 2014, after continuous growth which, with a mild slowdown in 2005 and 2009 began as early as in 2001, with considerably advanced scope of foreign exchange during the period 2010-2014. After the highest recorded value in 2014, the score of Serbian food manufacturing foreign exchange decreased in 2015, but it recovered in 2016 and approached the highest level in 2014.

Table 1. Export characteristics of food manufacturing of Republic of Serbia during the period 1996-2016

\begin{tabular}{|l|r|r|r|r|r|r|r|r|r|c|}
\hline & $\mathbf{1 9 9 6}$ & $\mathbf{2 0 0 0}$ & $\mathbf{2 0 0 5}$ & $\mathbf{2 0 1 0}$ & $\mathbf{2 0 1 1}$ & $\mathbf{2 0 1 2}$ & $\mathbf{2 0 1 3}$ & $\mathbf{2 0 1 4}$ & $\mathbf{2 0 1 5}$ & $\mathbf{2 0 1 6}$ \\
\hline Export* & 519 & 290 & 885 & 2,189 & 2,407 & 2,638 & 2,711 & 2,985 & 2,806 & 3,124 \\
\hline Import* & 584 & 345 & 740 & 983 & 1,259 & 1,408 & 1,533 & 1.557 & 1,508 & 1,345 \\
\hline $\begin{array}{l}\text { Foreign trade } \\
\text { exchange* }\end{array}$ & 1,103 & 636 & 1,626 & 3,172 & 3,666 & 4,046 & 4,244 & 4,542 & 4,314 & 4,469 \\
\hline Trade balance* & -65 & -55 & 145 & 1,205 & 1,147 & 1,230 & 1,178 & 1,428 & 1,298 & 1,779 \\
\hline $\begin{array}{l}\text { Coverage of } \\
\text { import by export }\end{array}$ & 88.9 & 84.0 & 119.6 & 222.6 & 191.1 & 187.4 & 176.8 & 191.7 & 186.1 & 232.3 \\
\hline $\begin{array}{l}\text { Share in } \\
\text { the export } \\
\text { economy** }\end{array}$ & 28.2 & 17.0 & 17.5 & 22.3 & 20.4 & 23.5 & 18.6 & 20.1 & 21.0 & 21.0 \\
\hline $\begin{array}{l}\text { Share in import } \\
\text { economy ** }\end{array}$ & 14.2 & 9.3 & 7.1 & 5.9 & 6.3 & 7.4 & 7.5 & 7.6 & 8.3 & 7.0 \\
\hline
\end{tabular}

Note: * in thousands US\$, ** in \%.

Source: Calculation of the author based on the data obtained from UNCTADstat database

During the period 1996-2005 Serbian food manufacturing had negative foreign trade balance (deficit). Beginning with 2005 it realised surplus which significantly increased during the period 2007-2010. The value of surplus in foreign-trade exchange had a slightly cyclic movement during the period 2011-2015, to increase significantly in 2016.

The share of food manufacturing in total export had pronounced cyclic trend and it reached $19.7 \%$ on average. The greatest share of food manufacturing in total export was in 1996 (28.2\%), while the lowest was in 1998 (14.1\%), and in 2006 and 2007 (14.5\% and $14.4 \%$, respectively). After the low value which was recorded in 2007 , the share of food manufacturing in total export economy in the following two years significantly rose (in 2009 it was $22.8 \%$ ) and in the subsequent period in ranged from $18.6 \%$ in 2013 to $23.5 \%$ in 2012 . In 2016, the share of food manufacturing in total export was $21.0 \%$, which was approximate to the share noted in $1999(21.6 \%) ; 2004$ (20.6); 2011 (20.4); and 2014 (20.1\%). 
Graph 1. The position of food manufacturing in foreign-trade exchange of Republic of Serbia

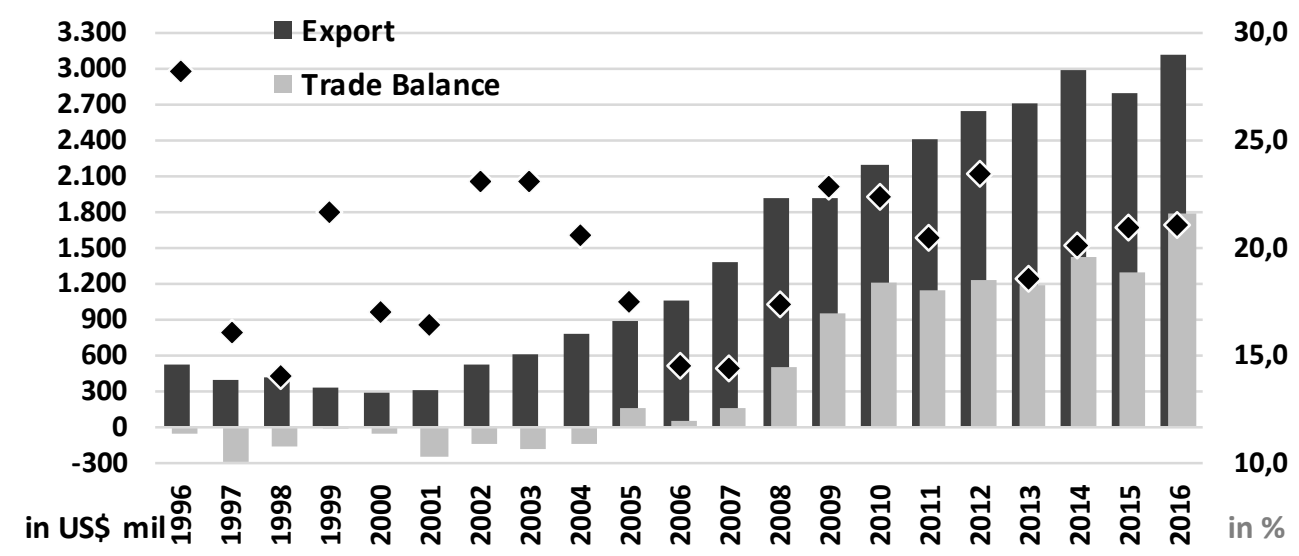

Source: Calculation of the author based on the data obtained from UNCTADstat database

The share of food manufacturing in the total import was $8.7 \%$ on average during the period 1996-2016. Food manufacturing recorded the greatest share in import in 1996 and 1997 (14.2\%, respectively), while the lowest was during the period 2007-2010, when the share of food manufacturing in the import ranged from $5.9 \%$ to $6.1 \%$. In 2005 , the share of food manufacturing in the import was $8.3 \%$, to decrease to $7.0 \%$ in 2016, which was approximate to the level in 2005 and 2006, and below the level in 2012-2015.

During the observed period from 1996 to 2016, the value of the exported products of food manufacturing of Serbia exceeded the value of the imported products in the same sector, thus the coverage of import by export was $131 \%$ on average, i.e. the value of export exceeded the value of import by 31\%. Unlike the period 1996-2004, when the coverage of export by import was negative due to higher import than export, during the period 2005-2016, the export exceeded import to reach its highest coverage in 2010 and 2016, when the coverage of import by export amounted $222.6 \%$ and $232.6 \%$, respectively.

\section{Competitiveness at the level of the industry: concept and indicators}

In contemporary globalised economic conditions the necessity for realisation of business activities on the international market has become increasingly pronounced. It is becoming crucial factor of economic development for a great number of countries, including the Republic of Serbia as a small open economy.

In order to realise export activities it is necessary to create and develop international competitiveness. It is not possible to build and improve competitiveness only single dimensionally because it is a pronouncedly complex and dynamic phenomenon. Therefore, the development of competitive advantages is necessary for not only specific products and economic subjects, but also economic and manufacturing industries and 
national economy as a whole. In the greatest number of countries today, the essence of competitiveness includes structure and development of industry together with the method by which enterprises acquire and maintain their competitive advantages.

The concept of international competitive advantage involves the capability of enterprises, industries and economies to build own competitive position within the national market by using international criteria and key factors of competitiveness which dominate over specific activities. In this concept, the most significant drivers of competitive advantages are permanently created and searched for. Therefore, international competitiveness implies the capability of an enterprise, a sector and whole economy to develop individual competitive position within a national market, but according to international criteria. At microeconomic level the methodology of measuring competitiveness is mainly harmonised; it refers to the analysis of certain indicators related to specific market segments where an individual enterprise is active, as well as to its market position. The indicators of competitiveness of an enterprise that are related to its market share at given moment and the change of market share are most often used. Other significant indicators include the growth of profit, increasing number of employees, growth and efficiency of investments, growth of productiveness, improvement of innovativeness, use of information technologies, growth of shares, changes of sales on domestic and foreign markets and evaluation of capability of an enterprise to maintain and develop during long term in the conditions of growing international competitiveness.

On the other hand, various attitudes about measuring national competitiveness can be found. The level of competitiveness of counties can be analysed by using different methodologies and indicators. The quantification of competitiveness was relatively simple when it was reduced to production capabilities with lower expenses. Then, comparative analysis of expenses was used as a base in consideration of competitiveness.

In economic literature a greater number of export competitiveness can be found, i.e. quantitative, qualitative and structural changes of export. The starting point is that quantitative evaluation of international competitiveness is possible to achieve by follow up of the share of national economy on international market, export share in world export, the export per capita, current payment balance, changes of exchange rate, productivity or the cost of labour. The used indicators are directed on results or inputs.

The indicators that are directed towards results provide the detection of ex-post competitive position and are used for determination of competitiveness at the level of sectors and on international market. The following indicators of export competitiveness of a country and specific manufacturing industry are specifically pronounced for their significance: Revealed comparative advantage (Balassa index or specialisation index) - RCA, Competitiveness growth index - RCA1, Index of net business performanceRCA2, Index of contribution to the trade balance - CTB, Grubel-Lloyd index - GLI and Michaely index - MI (Sujová, Hlaváčková, Marcineková, 2015).

RCA is the most often used indicator of export competitiveness. It quantifies comparative advantage of a country in international exchange of a certain product, 
i.e. comparative advantage of production in certain industry. (Rybakovas, 2009). It exists in a few forms. In accordance with the methodology of International World Centre UNCTAD and processing of World Trade Organisation (WTO), the analysis in the domain of development of trade considers the difference between net export, existing specialisation, trade deficit and theoretical net export. It does not include the analysis of reasons that lead to comparative advantages of a country in the international exchange, but detects present comparative advantages based on data on export results of certain groups of products in the world export, while by comparing various periods, it determines whether the change of export structure is realised, and whether comparative advantages change by groups of products with more or less value added.

The formula for calculation of indicators of comparative advantages was developed by Bella Balassa, presenting the so-called "Balassa index" or "Revealed Comparative Advantage" (RCA) in 1965, which was later readjusted and modified (Hinloopen, Marrewijk, 2001). This index is still most frequently used method for measuring comparative advantages of economies of specific countries in the international trade (Amighini, Leone, Rabellotti, 2011). Balassa index shows comparative advantage or lack of export and its competitive capability. Thus the following formula is obtained:

$\mathrm{RCA}=\ln [(\mathrm{xsc} / \mathrm{msc}) /(\mathrm{Xc} / \mathrm{Mc})]$, whereby:

$\mathrm{x}_{\mathrm{sc}}$ - is export value of sector " $\mathrm{s}$ " of the country " $\mathrm{c}$ ",

$\mathrm{m}_{\mathrm{sc}}$ - is import value of sector "s" of the country "cc",

$\mathrm{X}_{\mathrm{c}}$ - is the value of total export of the country " $\mathrm{c}$ ",

$\mathrm{M}_{\mathrm{c}}$ - is the value of total import of the country " $\mathrm{c}$ ".

$\mathrm{RCA}<0$ points to comparative disadvantages of a product; $\mathrm{RCA}>0$, points to the existence of certain comparative advantage in the export of product or industry to which the product belongs, and RCA $>1$ points to internationally competitive product and industry (Klodt, 1993).

More significant modification of Balassa RCA formula was done by Austrian Institute for Economic Research - WIFO Vienna, in order to enable the expression of competitiveness at national level (Aiginger, Landesman, 2002). Based on WIFO methodology, Competitiveness growth index - RCA1 was obtained, which enables measuring the competitiveness of economy on regional and global markets.

Competitiveness growth index - RCA1 is obtained by comparison of export of certain commodity group in total export of the observed country in relation to the value of global export of the observed commodity group and total global value of export, and is calculated by using the formula $\mathrm{RCA} 1=\left(\mathrm{x}_{\mathrm{sc}} / \mathrm{X}_{\mathrm{c}}\right) /\left(\mathrm{X}_{\mathrm{s}} / \mathrm{X}\right)$. When $\mathrm{RCA} 1>1$ it reveals comparative advantage of industry on global market and when $\mathrm{RCA} 1<1$, the group of commodities has no competitive capability on the relevant market.

$\mathrm{X}_{\mathrm{sw}}$ - export value of the sector $s$ in the world,

$\mathrm{X}_{\mathrm{s}}$ - total value of the export in the world. 
Index of net business performance - RCA2 quantifies the contribution of a certain sector to creation of active trade balance, i.e. comparative advantage of export industry or a product and its competitive capability (Balassa, 1965). It is obtained as a percentage difference between export and import sector and sum of export and import of those sectors, and is calculated by using the formula $\mathrm{RCA} 2=\left(\mathrm{x}_{\mathrm{sc}}-\mathrm{m}_{\mathrm{sc}}\right) /\left(\mathrm{x}_{\mathrm{sc}}+\mathrm{m} s c\right)$. When $\mathrm{RCA} 2=-1$, it means that no export exists $\left(\mathrm{x}_{\mathrm{sc}}=0\right)$, and when $-1<\mathrm{RCA} 2<0$, it points to comparative disadvantages. When $\mathrm{RCA} 2=0$, export $=$ import, when $0<\mathrm{RCA} 2<1$, it points to the revealed comparative advantage and when RCA $2=1$ it means that no import exists $\left(\mathrm{m}_{\mathrm{sc}}=0\right)$.

Index of contribution to the trade balance - CTB measures the contribution of certain sectors to national trade balance. It is obtained as difference between real and expected balance in economy (Melisek, 2012) and is calculated by using the following formula

$$
\mathrm{CTB}=\frac{x_{s c}-m_{s c}}{x_{c}+M_{c}}-\frac{x_{c}-M_{c}}{x_{c}+M_{c}} \times \frac{x_{s c}+m_{s c}}{x_{c}+M_{c}} \times 100
$$

The left part of equation is a real trade balance of the industry which is pondered by its share in total foreign exchange of a country, which is inter-sector trade. The right part of equation measures the expected trade balance of a sector, if each sector contributes to the total trade balance according to its share in total trade. The difference between the real and expected trade balance quantifies specific contribution to total trade balance. $\mathrm{CTB}>0$ means that real surplus is higher than expected and relative trade deficit is lower than expected, thus the sector has positive contribution to total trade balance; $\mathrm{CTB}<0$ means that the sector has negative contribution to total trade balance, and real results in comparison to the expected are negative or insufficient.

Grubel-Lloydov index - GLI is most often applied in the quantification of intramanufacturing trade, i.e. capacity of countries to utilise economy of scope (Grubel, Lloyd, 1971). GLI measures export capability on macroeconomic level, i.e. analyses the degree of presence of commodities with inter-sector character in foreign trade, whereby higher degree of presence points to higher degree of national competitiveness. The index is modified for evaluation at the level of industry and its calculation shows a degree of presence of commodities in inter-sector foreign trade exchange of a country.

It is calculated by using the formula:

$$
\text { (Grubel, Lloyd, 1971). } \mathrm{GLI}=1-\frac{\frac{x_{S c}}{X_{C}}-\frac{m_{S C}}{M_{C}}}{\frac{x_{S c}}{X_{C}}+\frac{m_{S C}}{M_{C}}}
$$

GLI value moves within the interval from 0 to $1(0<\mathrm{GLI}<1)$. The closer it is to 1 it reveals approximately the same structure of production and export, i.e. higher complementarity of the two markets and vice versa. The comparing value should be mean value of GLI for all sectors in the country, or global value of the given sector (commodity group). 
Michaely index - MI shows the degree of specialisation or the lack of specialisation of the country in commodity group or industry (Michaely, 1962). It measures the share of commodity group in total national export and share of commodity group in total national import. It is calculated by using the formula

$$
M I=\frac{x_{s c}}{\sum_{i=1}^{n} X_{c}}-\frac{m_{s c}}{\sum_{i=1}^{n} M_{c}} .
$$

When the value of index ranges $0<\mathrm{MI}<1$ it points to a certain degree of specialisation of a country in the commodity group, while when the value ranges $-1<\mathrm{MI}<0$, it points to insufficient specialisation of the country in the commodity group.

Coefficient of correlation - $r$ is a statistical method of correlation analysis by which the degree of mutual dependence of two connected variables is measured and calculated by using the formula:

$$
\operatorname{Correl}(X, Y)=r=\frac{\sum(x-\bar{x})(y-\bar{y})}{\sqrt{\sum(x-\bar{x})^{2} \sum(y-\bar{y})^{2}}}
$$

Where $\mathrm{x}$ is dependent and $\mathrm{y}$ is independent variable.

The strength of connection between variables is expressed in numerical values of coefficient of correlation which range from $+1,0$ to $-1,0$, so the closer the coefficients are to $1(+1,0$ and $-1,0)$, the stronger connection between the variables is.

\section{Research results}

Measuring export competitiveness of food manufacturing begins with the capability of domestic enterprises to successfully recognise and satisfy the needs of domestic and foreign customers in the conditions of fair competitive competition with the enterprises from other countries, i.e. to sell their products on domestic and international markets and use production factors more efficiently and better adapt to the conditions in their surroundings (macroeconomic, social, ecological, political etc.).

The selection of indicators of competitiveness at the level of food manufacturing is determined by an attempt to achieve the answer to the issue whether food manufacturing of Serbia is competitive on domestic and international markets. The proof of competitiveness is in greater amount of domestic products which are placed on foreign markets, in comparison to the scope of foreign products in the same sector of food manufacturing that are placed on domestic market, in the conditions of free trade exchange and fair competition. The information about these facts can be obtained by calculating the coefficients RCA, RCA1 and RCA2, as well as coefficients CTB, GLI and MI. Time analysis of change of competitiveness indicator value shows the change of competitiveness of food manufacturing of Serbia regarding its increase or decrease during the considered time interval of twenty years (Table 2). 
Table 2. Indicators of competitiveness of food manufacturing of Serbia during the period 1996-2016

\begin{tabular}{|l|r|r|r|r|r|r|r|r|r|r|r|}
\hline $\begin{array}{c}\text { Indicator/ } \\
\text { year }\end{array}$ & $\mathbf{1 9 9 6}$ & $\mathbf{2 0 0 0}$ & $\mathbf{2 0 0 5}$ & $\mathbf{2 0 1 0}$ & $\mathbf{2 0 1 1}$ & $\mathbf{2 0 1 2}$ & $\mathbf{2 0 1 3}$ & $\mathbf{2 0 1 4}$ & $\mathbf{2 0 1 5}$ & $\mathbf{2 0 1 6}$ & $\begin{array}{c}\text { Average } \\
\text { of the } \\
\text { period }\end{array}$ \\
\hline RCA & 0.683 & 0.600 & 0.904 & 1.336 & 1.170 & 1.150 & 0.911 & 0.979 & 0.929 & 1.101 & 0.841 \\
\hline RCA1 & 3.097 & 2.537 & 2.665 & 3.016 & 2.731 & 3.132 & 2.410 & 2.542 & 2.552 & 2.429 & 2.610 \\
\hline RCA2 & -0.059 & -0.087 & 0.089 & 0.380 & 0.313 & 0.304 & 0.278 & 0.314 & 0.301 & 0.398 & 0.081 \\
\hline MI & 0.139 & 0.077 & 0.104 & 0.165 & 0.141 & 0.161 & 0.111 & 0.126 & 0.127 & 0.140 & 0.110 \\
\hline CTB & 7.046 & 4.314 & 3.648 & 3.173 & 2.996 & 3.465 & 2.073 & 2.124 & 2.130 & 1.737 & 3.998 \\
\hline GLI & 0.671 & 0.709 & 0.577 & 0.416 & 0.474 & 0.481 & 0.574 & 0.546 & 0.566 & 0.499 & 0.610 \\
\hline
\end{tabular}

Source: Calculation of the author based on the data taken from the UNCTADstat database

The average value of RCA index during the period 1996-2016 was 0.841 . The fact that in all the observed years the values of RCA were positive shows that food manufacturing in Serbia has certain comparative advantages on domestic and export markets.

The index of growth of competitiveness had higher value than 1 (the average value was 2.610) during whole period, which points to significant degree of competitiveness of Serbian food manufacturing on the international market, while cyclic changes of values of indicators show that open competitive advantage was not based on sufficiently strong basis, i.e. the issue of its long-term sustainability is reasonably questioned.

Positive values of the indicator of net trade exchange (ECA2) during the period 2005-2016 show positive contribution to foreign trade balance of economy and the existence of revealed comparative advantage of domestic food manufacturing on domestic market. It was not the case during the period 1996-2004, when food manufacturing had negative influence on the change of foreign trade balance due to significant comparative shortcomings (Graph 2)

Graph 2. Change of values of indicators RCA, TCA1 and RCA2 for food manufacturing in Serbia during the period 1996-2006

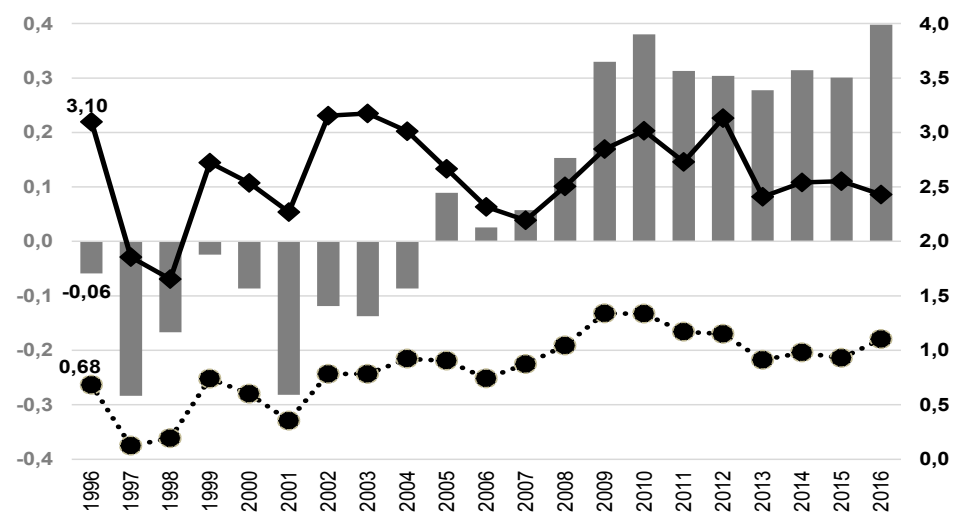

Source: Calculation of the author based on the data taken from UNCTADstat database 
The indicator of net trade exchange (RCA2) is connected with the index of contribution to trade balance (CTB) which points to positive contribution of the sector in creation of active national trade balance and economic growth during the period 2005-2006, i.e. negative influence of the sector of food manufacturing in the creation of foreign trade balance during the period 1996-2004.

The average value of CTB index of food manufacturing $(\mathrm{CTB}=0.9362)$ and positive annual values of CTB in food manufacturing show positive contribution of the sector in total trade balance and presence of real surplus, which exceeded the expectations, with relative deficit lower than expected, which is especially noticeable during the period 1996-2004 (Graph 3).

Graph 3. Change of values of indices CTB GLI and MI for food manufacturing in Serbia during the period 1996-2016

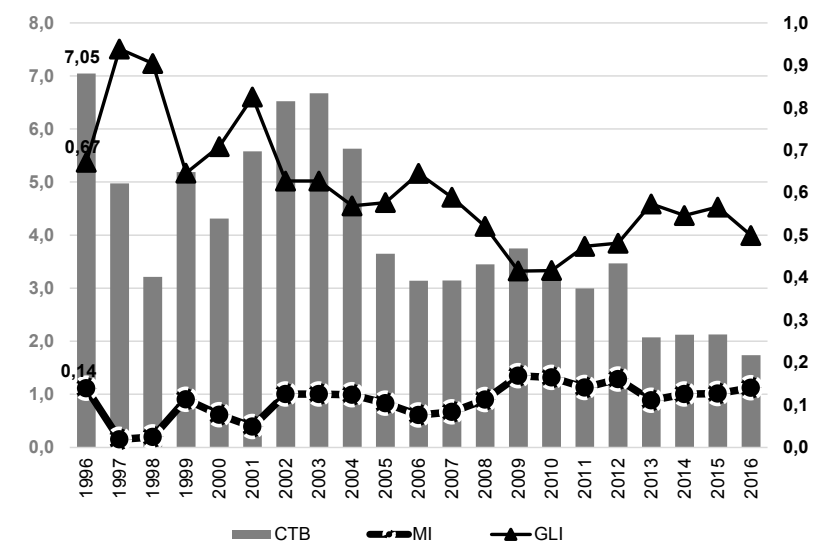

Source: Calculation of the author based on the data taken from UNCTADstat database

The average $(\mathrm{MI}=0.110)$ and positive annual values of Michaely index confirmed certain competitiveness of domestic food manufacturing, but also its low specialisation as a whole during the observed period.

The values of GLI show first high and then decreasing degree of presence of products of food manufacturing in inter-sector foreign exchange. This points to the decrease of capability of a sector to create surplus of national trade balance (the average value of GLI index of food manufacturing in Serbia is 0.610). 
Figure 4. Indicators of competitiveness of food manufacturing in Serbia

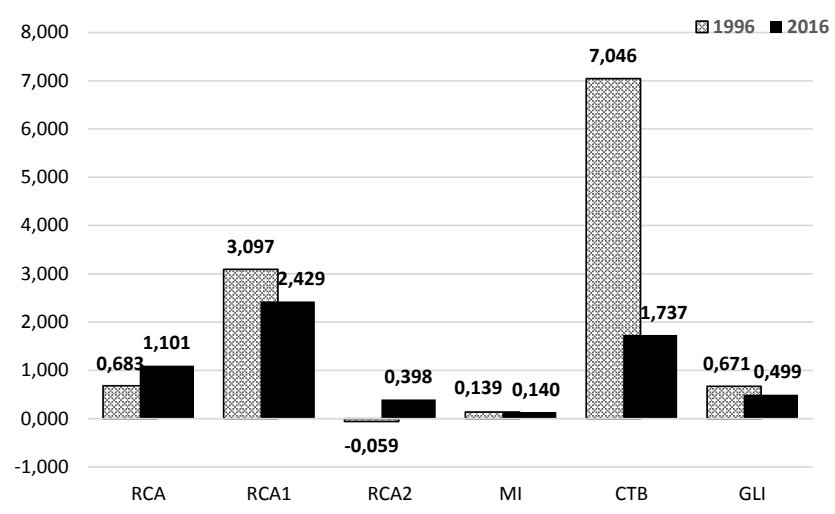

Source: Calculation of the author based on the data taken from UNCTADstat database

In order to reveal factors which influence comparative values of food manufacturing in Serbia, by using the statistical method of correlation analysis the coefficients between y (RCA, RC1, RC2, CRB and MI) and x (MI, GLI, Export FI RCA) were calculated, whose values showed the degree of dependence between the selected indicators of competitiveness of food manufacturing in Serbia (Table 3).

Table 3. Coefficients of correlation

\begin{tabular}{|l|r|r|r|r|r|}
\hline \multicolumn{1}{|c|}{ Correlation } & \multicolumn{5}{|c|}{$\mathbf{y}$} \\
\hline MI & \multicolumn{1}{c|}{ RCA } & \multicolumn{1}{c|}{ RCA1 } & \multicolumn{1}{c|}{ RCA2 } & \multicolumn{1}{c|}{ CTB } & \multicolumn{1}{c|}{ MI } \\
\hline GLI & 0.9091 & 0.8262 & 0.7328 & -0.0959 & \\
\hline Export FI & -0.9975 & -0.6282 & -0.8553 & 0.3770 & -0.9121 \\
\hline RCA & 0.4686 & 0.8410 & 0.2942 & 0.3748 & 0.7894 \\
\hline
\end{tabular}

Source: Calculation of the author based on the data taken from UNCTADstat database

The presented coefficients of correlation in Table 3 show both positive and negative connection between certain indicators of foreign trade competitiveness of food manufacturing of Serbia in the period 1996-2016. Also, it is noticed that strong mutual connection of the analysed indicators of foreign trade competitiveness of food manufacturing in Serbia is predominant. Namely, out of the total of eighteen presented coefficients of correlation, five show very high correlation (above 0.91), eight show high correlation (0.71-0.90), three show significant correlation (0.41-0.70), one shows low (0.21-0.40) and one is nearly without correlation (0-2.0)

\section{Discussion}

In the period 1996-2009, although with pronounced cyclic deviation, the increasing values of RCA index show that comparative advantage of food manufacturing of 
Serbia gradually increased on both domestic and foreign markets. However, after 2011, comparative advantage of domestic food manufacturing permanently decreased, with certain recovery in 2016.

The previous results are largely confirmed by the average value and changes of values of RCA1 index. The obtained values of this indicator point to relatively high but changeable competitiveness of food manufacturing of Serbia on the international market during the whole observed period.

During the period 2005-2016, positive values of net trade exchange (RCA2) show positive contribution of food manufacturing to foreign trade balance of the country, unlike the period 1996-2004, when that influence was negative.

The index of trade balance (CTB) shows positive contribution of the food manufacturing sector in total trade balance, even real surplus exceeded the expected, i.e. relative deficit was lower than expected, which was the case during the period in 1996-2004, while after 2004, real surplus permanently decreased although the sector made surplus, since the real surplus was lower that the really possible.

During the period 1996-2016, the constant fall of GLI was present with obvious cyclic changes (e.g. from 0.968 points in 1997 to 0.49 points in 2016), which undoubtedly points to the necessity of change in the structure of food manufacturing in Serbia and its turn towards the trend of higher specialisation and production of groups of food products with higher value added, in order to achieve increased GLI. The countries with higher Grubel-Lloyd index have better manufacturing differentiation and growth of productivity due to economy of scope. Significant increase of share of intramanufacturing trade in total trade would mean sustainable manufacturing development and decrease of technological gap in food manufacturing and Serbian economy as a whole in relation to the developed countries.

The change of MI values shows certain increase in specialisation of production in food manufacturing of Serbia during the period until 2010, and also its decrease after 2012. However, a pronounced cyclic character of annual evaluation of indicators, together with the fact that in 2016 the specialisation of production was realised at the same level as in 1996 point to an insufficient degree of specialisation of domestic food manufacturing and strong need for higher specialisation on qualitatively higher bases.

The results of analysis of dependence between the selected indicators by using the method of statistical correlation show that the competitiveness of the sector of food manufacturing is under a strong influence of the following factors:

- The level of specialisation of the country for the products of sector,

- High level of inter-sector foreign trade exchange of the country,

- Export performances of the sector at national level,

- The share of sector in export of the country which has mainly positive contribution, of the sector to active foreign trade balance of the country.

EP 2018 (65) 1 (49-64) 
Since the research in competitiveness of food manufacturing is insufficiently focused on the methods by which the enterprises in this sector should improve the activities which create higher value added and thus increase their competitiveness, the development of those activities within the chain of values is still the basis for improvement of total competitiveness of enterprises of food manufacturing, both in the country and worldwide.

Bearing in mind the fact that food industry is a set of complementary, but often mutually technologically various activities (Food and live animals; Beverages and tobacco; Oil seeds and oleaginous fruits; and Animal and vegetable oils, fats and waxes) with various roles in the chain of values, it follows that various activities have various bearers of competitiveness. Therefore the development of long-term competitiveness in the domain of food manufacturing cannot be based on the exploitation of natural resources only, but it has to be increasingly established on production and market realisation of technologically complex products and services with higher value added which, only in their basis, rely on intensive exploitation of various kinds of raw materials of vegetative and animal origin.

\section{Conclusion}

Food manufacturing produces a wide range of internationally exchangeable products of various technological complexity, life span and monetary value. At the same time, these products satisfy existential needs of people, and on the other hand, their consumption is under a significant influence of various social and religious norms, and increasingly fashion trends, which makes competitiveness of food manufacturing mainly different from the competitiveness of other sectors of economy. Pronounced fragmentation of its structure and its increasing exposure to pressure of progressively concentrated and globally profiled retailed sector only complicate already rigorous conditions for competitiveness in food manufacturing.

Although with the most significant comparative advantages, export competitiveness of food manufacturing of Serbia is at significantly lower level in comparison to the really possible and necessary level. Weakness of competitiveness of food manufacturing of Republic of Serbia is seen in the fact that it is predominantly realised on the basis of extensive production and export of primary agricultural products (cereals, raspberries, apples etc.) of law price and value added, not on the basis of manufacturing complex food products of high quality and high value added.

In order to improve competitiveness of food manufacturing on domestic and global markets, it is necessary for domestic food enterprises to adopt the latest productive, managing and marketing techniques, whose consistent application will contribute to the growth of manufacturing and export of food products and maintain the existing level of employment with favourable labour conditions and higher income level. This will enable domestic food enterprises to fulfil increasing needs of domestic and foreign customers more efficiently, faster and more effectively react to changeable conditions in global environment, significantly increase the scope and quality of production and export, and make domestic food manufacturing competitive on global market for a long time. 


\section{Literature}

1. Aiginger, K., Landesmann, M. (2002): Competitive Economic Performance: The European View, WIFO Working Papers, No 179, Wienna: Austrian Institute of Economic Research.

2. Amighini, A. Leone, M., Rabellotti, R. (2011): Persistence versus Change in the International Specialization Pattern of Italy: how much does the 'Direct Effect' Matter?”, in Regional Studies 45, pp. 381-401

3. Balassa, B. (1965): Trade liberalisation and "revealed" comparative advantage. The manchester school, Vol 33 No2, pp. 99-123.

4. Grubel, H., Lloyd, P. (1971): The Empirical Measurement of Intra-Industry Trade, Economic Record, Vol 47 No120, pp. 494-517.

5. Hinloopen, J., van Marrewijk, C. (2001): On the empirical distribution of the Balassa index, Weltwirtschaftliches Archiv / Review of World Economics Vol 137 No 1, pp. 1-35.

6. Klodt, H. (1993): Europäische Industriepolitik nach Maastricht, Weltwirtschaftliches Archiv. 263 ff.

7. Melišek, I. (2012): Meranie a hodnotenie makroekonomických výsledkov zahraničného obchodu. Ekonomické rozhl'ady, Vol 41 No 4, pp. 439-451.

8. Michaely, M. (1962): Multilateral balancing in international trade. The American Economic Review, 52(4), 685-702.

9. Rybakovas, E. (2009): Competitiveness of Lithuanian manufacturing industry, Economics and management, Vol. 14, pp. 912-918.

10. Sujová, A., Hlaváčková, P., Marcineková, K. (2015): Measuring the Impact of Foreign Trade on Performance Growth of the Woodprocessing Industry. Wood Research, Vol 60 No 3, pp. 491-502.

11. UNCTADstat database available at http://unctadstat.unctad.org/wds/TableViewer/ tableView.aspx?ReportId=24738

12. http://wits.worldbank.org/wits/wits/witshelp/Content/Utilities/e1.trade_ indicators.htm 


\title{
KONKURENTNOST PREHRAMBENE INDUSTRIJE REPUBLIKE SRBIJE
}

\author{
Dušanka Jovovićc ${ }^{3}$, David Jovovic ${ }^{4}$
}

\section{Sažetak}

Predmet rada je izvozna konkurentnost prehrambene industrije Republike Srbije u periodu 1996-2016. Analiza izvozne konkurentnosti je realizova pomoću indikatora Revealed comparative advantage (RCA), Competitiveness growth index (RCA1), Index of net business performance (RCA2), Index of contribution to the trade balance (CTB), Grubel-Lloydov indeks (GLI) and Michaely index (MI). Rezultati su pokazali da su vrednosti RCA bile pozitivne u svim godinama, što govori o komparativnoj prednosti ove grane industrije na domaćem tržištu. Budući da su vrednosti RCAlveće od jedan, znači da je ona bila i izvozno konkurentna. Postojanje pozitivnih vrednosti RCA2 u periodu 2005-2016. svedoči o doprinosu prehrambene industrije spoljnotrgovinskom bilansu srpske privrede. Prosečna vrednost CTB indeksa iznosi 3,998 i njegove pozitivne godišnje vrednosti pokazuju da je doprinos prehrambene industrije ukupnom trgovinskom bilansu pozitivan. Kretanje vrednosti GLI ukazuje na gubitak sposobnosti sektora da stvori višak nacionalnog trgovinskog bilansa. Pozitivne godišnje vrednosti MI potvrdile su konkurentnost prehrambene industrije, ali i njenu nedovoljnu specijalizaciju.

Ključne reči: izvozna konkurentnost, pokazatelji konkurentnosti grane, prehrambena industrija, Republika Srbija.

3 Redovni profesor, Pravni fakultet, Lole Ribara 29, 38220 Kosovska Mitrovica, 0643749133 , dusanka.jovovic@pr.ac.rs

4 Vanredni profesor, Poljoprivredni fakultet, Kopaonička bb, 38228 Lešak, 063203181, jovovicdavid1@gmail.com 